\title{
Monospot: a differential slide test for infectious mononucleosis
}

\author{
VIVIAN BASSON AND A. A. SHARP \\ From the Department of Haematology, Radcliffe Infirmary, Oxford
}

SYNOPSIS Sera collected from 372 patients with suspected infectious mononucleosis were examined for heterophile antibodies by the Paul-Bunnell and the Monospot test. Comparison of results showed the latter to be simple, time saving, and of sufficient specificity for routine use in the general laboratory.

For many years, the Paul-Bunnell reaction (Paul and Bunnell, 1932) to demonstrate the presence of heterophile antibodies to sheep red cells has been accepted as a specific test for establishing the diagnosis of infectious mononucleosis. Stuart (1935), Bailey and Raffel (1935), and Davidsohn and Walker (1935) independently differentiated the antibodies for Forssman antigen and those of serum sickness from infectious mononucleosis by the absorption patterns of sheep agglutinins. This differential test has proved to be accurate and specific, although time consuming.

In 1936, Beer reported that horse as well as other species of red cells reacted in a similar manner to sheep red cells, both in serum sickness and infectious mononucleosis but that titres for infectious mononucleosis heterophil antibodies were highest when the horse cells were used.

Hoff and Bauer (1965), using a formalinized suspension of horse red cells, showed that they could demonstrate specific agglutination of these cells with sera from patients with infectious mononucleosis. The authors claimed that the specificity of their test was $98.5 \%$.

Lee, Davidsohn, and Slaby (1968) commented on these findings and showed that, after selective absorption of the sera with guinea-pig kidney and ox cells, the sensitivity of infectious mononucleosis sera for horse red cells was higher than that for sheep red cells. Adapting this principle, Lee, Davidsohn, and Panczyszyn (1968) were able to devise a simple slide or spot test for specific heterophil infectious mononucleosis antibody.

The purpose of this paper is to report a comparison of a spot test for infectious mononucleosis heterophil antibody (Monospot, Ortho) with the

Received for publication 3 October 1968. classic Paul-Bunnell titre using sera derived from patients with suspected infectious mononucleosis.

\section{MATERIALS AND METHOD}

SERA The sera compared in this study were derived from patients with suspected infectious mononucleosis either in hospital or in the catchment area of the hospital. The population of Oxford being somewhat artificial, the majority of sera were obtained from undergraduates at Oxford University. All sera tested were received over a period of 10 weeks.

THE PAUL-BUNNELL TESTS These were carried out by a modification of Barrett's (1941) technique (Hobson, Lawson, and Wigfield, 1958). A positive result was recorded if the titre of heterophil antibody, after absorption with guinea-pig kidney, was $1 / 40$ or above The sera were inactivated at $56^{\circ} \mathrm{C}$ for 30 minutes.

THE MONOSPOT (ORTHO) TEST A $20 \%$ suspension of horse red cells was used in an isotonic $3.8 \%$ sodium citrate formulation.

Test procedure One drop of the neat sera to be tested is mixed on an opal glass slide with one drop of (1) a particulate suspension of guinea-pig kidney, and (2) a I suspension of beef red cell stroma, and mixed with a wooden applicator at least 10 times. Ten microlitres $\vec{N}$ $(10 \gamma)$ of the horse red cell suspension are then added $\sigma$ and mixed with each drop of absorbed serum. The $N$ mixture is left undisturbed for one minute and then $\mathrm{N}$ examined for the presence or absence of red cell agglutination (it is important that the mixture of red cells and test sera is not rocked or shaken to promote agglutination, during this latter period). If agglutination is stronger with the sera absorbed with guinea-pig kidney, the test is positive; if stronger with the sera absorbed with ox cell stroma, the test is negative. If agglutination is absent in both mixtures, the test is negative.

A known 'positive' and 'negative' control serum is tested with each batch of test sera.

None of the sera were inactivated before testing. 


\section{RESULTS}

Three hundred and seventy-two sera from patients with suspected infectious mononucleosis were tested by both tests in parallel (Table I).

TABLE I

SERA FROM 372 PATIENTS WITH SUSPECTED INFECTIOUS MONONUCLEOSIS TESTED IN PARALLEL

Paul-Bunnell Test

\begin{tabular}{lcc} 
Monospot Test & \multicolumn{2}{l}{ Paul-Bunnell Test } \\
\cline { 2 - 3 } & $\begin{array}{l}\text { Positive } \\
\text { (Titre 1/40) }\end{array}$ & $\begin{array}{l}\text { Negative } \\
\text { (Titre 1/40) }\end{array}$ \\
\hline Positive & 90 & 5 \\
Negative & 0 & 277
\end{tabular}

In 90 instances, the Paul-Bunnell titre after absorption of the sera with guinea-pig kidney was 1/40 or greater. All 90 sera gave clear-cut positive results with the Monospot test.

Two hundred and eighty-two sera gave negative results with the Paul-Bunnell test and 277 gave negative results with the Monospot test.

In five instances the Monospot test gave 'false' positive results. All five patients had clinical signs and symptoms suggesting infectious mononucleosis, but the Paul-Bunnell reaction was unequivocally negative. In all five the horse red cell suspension had passed the expiry date, ie, was over three months old.

CORRELATION OF THE PAUL-BUNNELL TITRE WITH THE MONOSPOT TEST The Paul-Bunnell titres of sera giving positive results with the Monospot test varied between $1 / 40$ and $1 / 20,480$. In 11 instances the titre was only $1 / 40$ and when the sera from these latter cases were tested by the Monospot test, the agglutination of the horse red cells was slower and less marked than in the other positive tests but nevertheless conformed with criteria for positive results. The five 'false' positive tests also showed this slower reaction.

AGE DISTRIBUTION Positive results by both methods were obtained with sera derived from patients between the ages of 11 and 42, with the majority of patients being in the 15-to-25 age group. This age distribution also applied to the negative results.

SEX DISTRIBUTION Of the patients whose sera gave unequivocally positive results, 57 were male and 33 were female.

\section{DISCUSSION}

The simplicity of the Monospot test commends its use in a busy laboratory, there being no need to inactivate the serum before use. This comparative trial has shown that the results obtained using the Monospot test compare very closely with the classical differential Paul-Bunnell test. If the five so-called 'false' positive results with the Monospot test are excluded then the correlation was $100 \%$.

These five false positive results were obtained with one batch of reagents containing a horse red cell suspension that was over three months old, and therefore past the expiry date recommended by the suppliers. Thus their exclusion from the numbers of true results is probably justified.

The correlation between the Paul-Bunnell test with a borderline positive titre $(1 / 40)$ and the Monospot test did not confirm the impression that horse red cells were any more sensitive than sheep red cells to the heterophil antibody in infectious mononucleosis as claimed by Lee et al (1968).

What is certain is that the Monospot test has adequate sensitivity and if used before the recommended expiry date possesses a high degree of specificity.

This 'spot' test does not quantitate the titre of the specific heterophil antibody as does the PaulBunnell reaction. However, this seems of little practical importance as the titre of heterophil antibody has not been found to correlate with the severity or duration of infectious mononucleosis or with the complications that may accompany or follow this disease.

The age distribution of the patients tested would appear to reflect the high incidence of infectious mononucleosis in the undergraduate population of Oxford. The sex distribution of cases shows no significant prediliction of the disease, but perhaps is of subjective interest if one considers that the undergraduate population in this city shows a male/female ratio of $5: 1$.

The Monospot test is simple and time saving and would appear to have sufficient specificity for routine use in confirming the diagnosis of infectious mononucleosis in any individual.

We are indebted to Ortho Diagnostics, who supplied the reagents for the Monospot test.

\section{REFERENCES}

Bailey, G. H., and Raffel, S. (1935). J. clin. Invest., 14, 228.

Barrett, A. M. (1941). J. Hyg. (Lond.), 41, 330.

Beer, P. (1936). J. clin. Invest., 15, 591.

Davidsohn, I., and Walker, P. H. (1935). Amer. J. clin. Path., 5, 455.

Hobson, F. G., Lawson, B., and Wigfield, M. (1958). Brit. med. J., $1,845$.

Hoff, G., and Bauer, S. (1965). J. Amer. med. Ass., 194, 351.

Lee, C. L., Davidsohn, I., and Slaby, R. (1968). Amer. J. clin. Path., 49, 3.

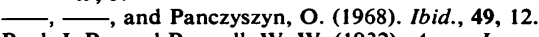

Paul. J. R., and Bunnell, W. W. (1932). Amer. J. med. Sci., 183, 90.

Stuart, C. A (1035). Proc. Snc. exp. Biol. (N. Y.), 32, 861. 